S. HOSHIKA, N. A. LEAL, M.-J. KIM, M.-S. KIM, N. B. KARALKAR, H.-J. KIM, A. M. BATES, N. E. J. WATKINS, H. A. SANTALUCIA, A. J. MEYER, S. DASGUPTA, J. A. PiCCIRILli, A. D. ELLINGTON, J. J. SANTALUCIA, M. M. GEORGIADIS, S. A. BENNER* (FIREBIRD BIOMOLECULAR SCIENCES LLC AND FOUNDATION FOR APPLIED MOLECULAR EVOLUTION, ALACHUA, INDIANA UNIVERSITY SCHOOL OF MEDICINE, UNIVERSITY OF CHICAGO UNIVERSITY OF TEXAS, AUSTIN, AND DNA SOFTWARE INC., ANN ARBOR, USA) Hachimoji DNA and RNA: A Genetic System with Eight Building Blocks Science 2019, 363, 884-887.

\section{Four New DNA Building Blocks}

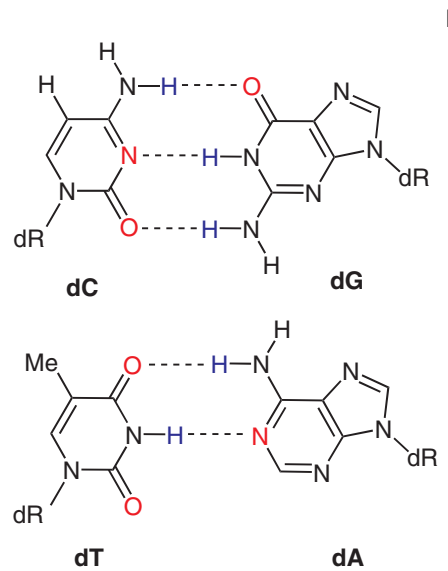

Hachimoji DNA

dT

dA

Representative synthesis of dS phosphoramidite:

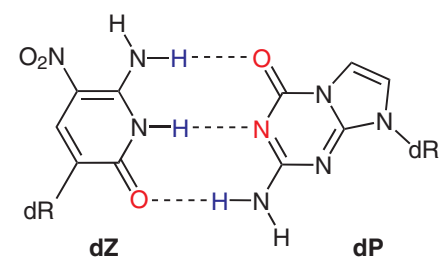

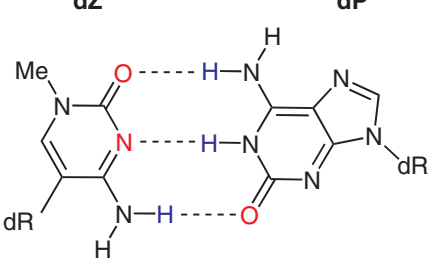

dS

dB

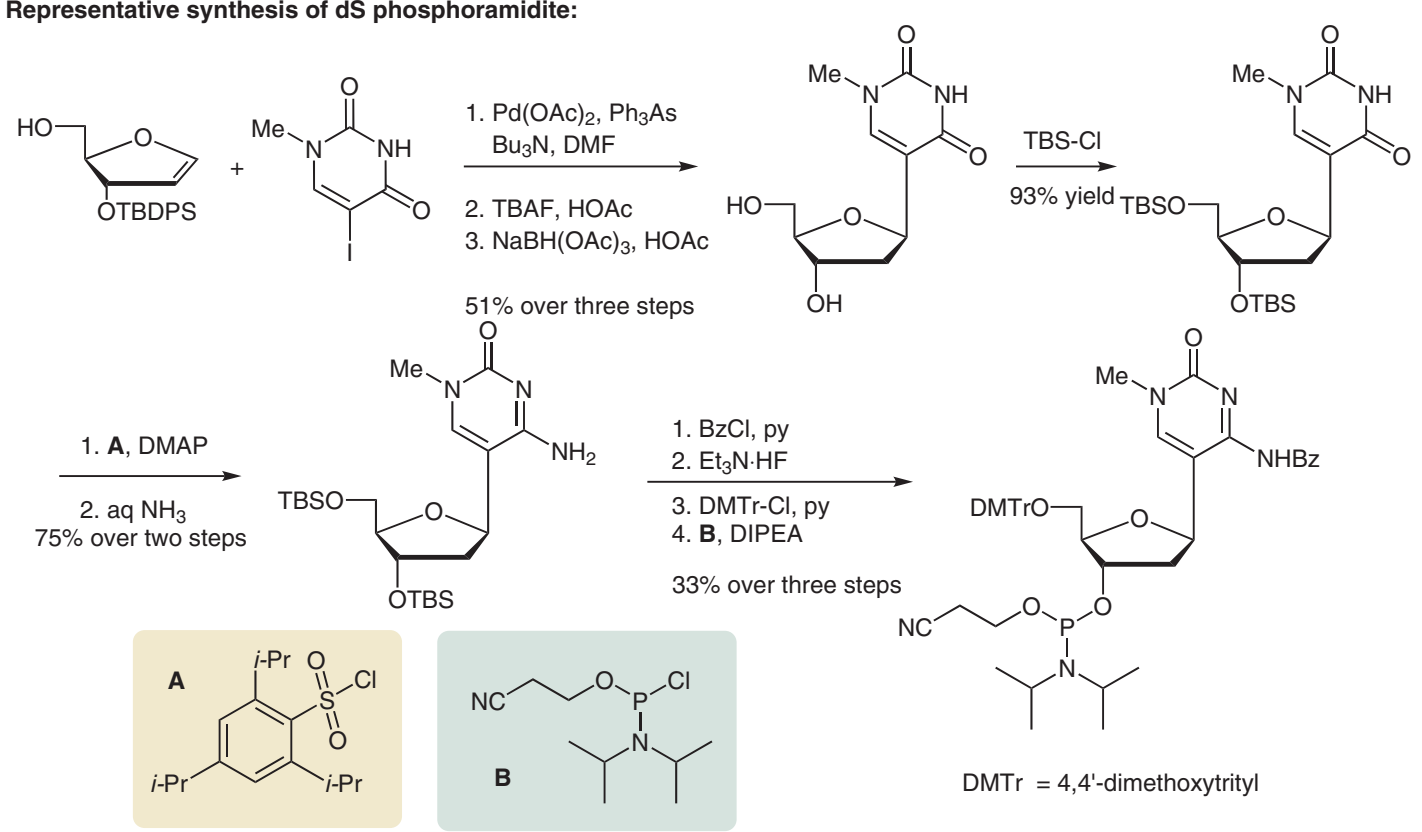

Category

Chemistry in

Medicine and Biology

\section{Key words}

\section{RNA}

DNA

nucleotides
Significance: An artificial genetic system, hachimoji DNA (from Japanese 'eight letters') has been obtained using novel nucleotides $\mathrm{P}, \mathrm{B}, \mathrm{Z}$, and $\mathrm{S}$ in combination with standard nucleotides. Hachimoji DNA builds structures with properties similar to those of natural DNA and can be transcribed into hachimoji RNA.
Comment: The synthesis of hachimoji DNA involves the novel purines $P$ and $B$ and the pyrimidines $Z$ and $S$ analogues. The representative synthesis of $d S$ phosphoramidite was reported previously by Benner and co-workers in Bioorg. Med. Chem. 2009, 17, 3728. 